Between Physicality and Symbolism: Kyiv as a Contested Territory in Russian and Ukrainian Émigré Letters, 1920-1939

Author(s): Mykola Iv. Soroka

Source: Kyiv-Mohyla Humanities Journal 5 (2018): 143-159

Published by: National University of Kyiv-Mohyla Academy

http://kmhj.ukma.edu.ua/ 


\title{
Between Physicality and Symbolism: Kyiv as a Contested Territory in Russian and Ukrainian Émigré Letters, 1920-1939
}

\author{
Mykola Iv. Soroka \\ Independent scholar (Edmonton, Canada)
}

\begin{abstract}
The paper deals with visions of Kyiv in the writings of Russian and Ukrainian émigré writers during the interwar period. The city became a focal point of intensive intellectual debate whose participants regarded Kyiv not only as a place of a recent battleground but also as a sacral place and a highly symbolic image. Within the methodological framework of ethnic symbolism, this study attempts to explain how this physical/ symbolic dichotomy was used to reinforce continuing claims for historical origin and cultural heritage, thus serving the contemporary purpose of national identity and political legitimacy. It also deploys the concept of displacement as a complex process of negotiation between homeland and hostland within an émigré community — whose sense of loss and identity crisis creates additional impetus, though in different forms, for exploiting historical narratives.
\end{abstract}

Key Words: Russian-Ukrainian relationship, ethnic symbolism, displacement, émigré writing.

\section{(7)}

How compelling is the importance and potent meaning that is attributed to certain cities and capitals. Jerusalem, Mecca, Rome, to name but a few, are imbued with reverential significance and mysticism as sacred sites and places of pilgrimage. They can be compared to the mind of a body of a country, and thus contain the most essential information about its culture, myths, and traditions, both past and present. The city's symbolic meaning serves as an unabating, phoenix-like, source of power, validation, and sacrifice. However, it becomes more complex when the city is contested between two peoples. Such a city is Kyiv (Kiev in Russian) - a critical imagistic representation in Russian and Ukrainian writings, which has permeated the émigré literary discourse of the interwar period. Kyiv has served not only as a focal point of recollections about the homeland and recent revolutionary past, but also as a powerful symbol and concept in the construction of national history and memory. Thus it has served the contemporary purpose of redefining national identity and political legitimacy. In this paper I will examine from a comparative perspective how Kyiv was reflected and appropriated in different genres of Russian and Ukrainian letters - essays, poetry and prose. The methodological framework will be the idea of ethnic symbolism, which 
I have borrowed from Anthony Smith, ${ }^{1}$ as well as the concept of displacement, which defines the dynamic relationship between homeland and hostland.

To be sure, there were other allegiances in multicultural Kyiv, which overlapped in the historical continuum. Among them were the Polish and Jewish ones. ${ }^{2}$ But certainly, the "fraternal rivalry" between Russians and Ukrainians has been of major significance and will likely determine the nature of this contested territory. This opposition came from the highly disputed issue of national identity that determined their prerevolutionary relations within the Russian imperial structure and which was also transplanted into emigration. This issue inevitably confronted the dilemma of national history and memory. Speaking specifically of the Russian-Ukrainian relationship, Zenon Kohut maintains that " $[\mathrm{H}]$ istory has been and continues to be a chief battleground in the struggle over identity."3 Smith considers ethnic symbols, myths, and other signs of national memory the most important factor in the formation of the cohesiveness of national groups. This paper also argues that Kyiv should be treated not only as a physical entity but also as a powerful symbol in the struggle for identity between the two Slavic groups.

Kyiv, as it is known, was included by most Russian historians into the dominant Russian historical paradigm that posits the emergence of Russian statehood from the medieval state of Kyivan Rus. While Moscow was attributed as pervoprestolnaia (the first throne) and a "third Rome" in Russian historical mythology, Kyiv appropriated a sacral meaning as a "second Jerusalem" — a place for travel and pilgrimage. "Kyiv is a cradle of the sacral faith of our ancestors, as well as the first witness of their civil life," noted tsar Nicholas I in his decree on November 8, 1833 regarding the foundation of a new university in the city. ${ }^{4}$ With the strengthening of the Russian empire and modernization of the city in the nineteenth century, there were even suggestions to move the imperial capital to Kyiv. The definition of Kyiv as "the mother of Rus towns," taken from old chronicles, was often utilized to support both imperial and Soviet interpretations of the origin of the three Eastern Slavic peoples-Russians, Ukrainians, and Belorusians. From the imperial point of view, Kyiv was the capital of the Russian people consisting of three tribes who spoke dialects of one Russian language. The Soviet paradigm allowed distinct Ukrainian and Belorusian identities (and their languages), which were formed after Moscow was subordinated to Mongol-Tatar rule in the 13th century but which would inevitably seek reunification.

1 See his works: Anthony Smith, Nationalism: Theory, Ideology, History (Cambridge: Polity Press, 2001), Anthony Smith, Ethno-Symbolism: A Cultural Approach (London; New York: Routlage, 2009).

2 See, e. g., Modernism in Kyiv: Kiev/Kyüv/Kiev/Kijów/Kiev:Jubilant Experimentation, ed. Irena R. Makaryk and Virlana Tkacz (Toronto: University of Toronto Press, 2006).

3 Zenon Kohut, History as a Battleground: Russian-Ukrainian Relations and Historical Consciousness in Contemporary Ukraine (Saskatoon: Heritage Press, 2001), 6. Viktor Kirkevich, Vremia Romanovykh: Kievv imperii [The Time of the Romanovs: Kyiv in Empire] (Kyiv: Tekhnika, 2004), 5 . 
This imperial attitude to Kyiv was reflected accordingly in Russian literary discourse starting from the travelogues (Izmailov and Glagolev) of the nineteenth century to such major works as Yama (The Pit) by Aleksandr Kuprin and Belaia gvardiia (The White Guard) by Mikhail Bulgakov. In Kuprin's Yama (published through 19o8-1915), e. g., this viewpoint appears as another imperial formula of Kyiv as "a large southern city," what Taras Koznarsky treated as "a gesture of symbolic 'dissolution' of Kyiv as a specific city into the universal space of the Russian Empire." This is what "purposely divorces Kyiv from any sense of its having a specific local historic and cultural tradition." ${ }^{5}$

Ukrainian romantics in their attempt to revive Ukrainian history and culture were the first in the modern period who tried to conceptualize Kyiv as a place of origin of the Ukrainian people. Many believed that it was what Mykola Hohol (Nikolai Gogol) claimed in his letter to Mykhailo Maksymovych, the first rector of Kyiv University, soon after the university had been opened in 1834: "Imagine, I was thinking: go, go to Kyiv, to ancient, beautiful Kyiv. It is ours, it is not theirs, is that not so? There, around (Kyiv), the events of our ancient history took place... There one can recuperate one's strength..." 6 At the beginning of the twentieth century, Ukraine's most celebrated historian Mykhailo Hrushevskyi in his seminal ten-volume Istoriia Ukrainy-Rusy (History of Ukraine-Rus') and other works gravely undermined the imperial scheme. He saw Kyiv as a center that laid the foundations for Ukrainian statehood, whereas Russia, in his opinion, had been formed around the Moscow, Vladimir, and Suzdal principalities.

These opposing views of Kyiv were brought into the interwar emigration. This was the largest mass exodus in the history of both nations, which included a number of prominent figures (e. g., Mykhailo Hrushevskyi, Dmytro Doroshenko, Viacheslav Lypynskyi, Pavel Miliukov, Nikolai Berdiaev, Dmitrii Odinets, Venedict Miakotin). The study of the émigré discourse is important because it offers a different and broader view of the subject. In the Soviet Union, after some political and cultural liberalism through the 1920s, any pluralism of intellectual freedom was severely suppressed because of Stalin's centralization of power in the 1930s. ${ }^{7}$ Thus, the emigration became a forum for an intense discussion on the Russian-Ukrainian relationship from various perspectives.

It is also important to note that emigration as a social and cultural phenomenon created a state of geographical displacement for both émigré communities - a state of being outside the homeland and subjected to its bipolar connection-physical (material, practical) and metaphysical (spiritual, symbolic, sentimental). Displacement always triggers questions of identity, homeland and history. "The basic response to such conditions," points out Andrew Gurr, "is a search for identity, the quest for a home,"

Taras Koznarsky, “Three Novels, Three Cities,” in Modernism in Kyiv: Kiev/Kÿ̈v/Kiev/Kijów/ Kiey: Jubilant Experimentation, ed. Irena R. Makaryk and Virlana Tkacz (Toronto: University of Toronto Press, 2006), 108.

6 V. I. Shenrok, ed., Pisma N. V. Gogolia [Letters by N. V. Gogol], vol. 1 (St. Petersburg, 1901), 268.

7 Even Hrushevskyi was forced to conform to the general party line in recognizing the new, Soviet, historical paradigm. See: Plokhy, Serhii. Unmaking Imperial Russia: Mykhailo Hrushevsky and the Writing of Ukrainian History (Toronto: University of Toronto Press, 2005). 
which may lead to a "search for a past, a cultural heritage." ${ }^{8}$ Kyiv, with its historical monuments, churches, and monasteries, as well as old narratives (stories, myths, and legends), was a natural core, where émigrés, Russian and Ukrainian alike, would search for their roots, creative inspiration, and hope for the future. But what were the mechanisms for their search in both groups?

Kyiv was seen exclusively as a Ukrainian city by Ukrainian émigrés. However, Russian émigrés of more liberal persuasion, like Odinets and Miakotin, pointed out that a shared history dating back to Kyivan Rus will always hang over the fate of both nations and thus determine one form or another of their inevitable unity, the most optimal one at the time being a federation. ${ }^{9}$ On the other hand, Russian monarchists and rightists, like Struve and Shulgin, did not recognize the Ukrainian nation and culture at all. Pavel Miliukov was probably the only Russian intellectual who did not emphasize the Kyivan period of Russian history and thereby aroused strong criticism among émigré intellectuals.

Within this general framework of the Russian-Ukrainian opposition, Kyiv was a focal point of the discussion. The most characteristic Russian work was the essay by the prominent philosopher and editor-in-chief of the journal Novyi grad (The New City), Georgii Fedotov. In "Tri stolitsy" (The Three Capitals) he speaks about St. Petersburg, Moscow, and Kyiv in historiosophic terms. For him, St. Petersburg, "a gloomy inhuman city on swamps," is a symbol of Russia's connection with Europe, imperialism, bureaucracy, and isolation from the people. Moscow, "the heart of Russia," is a simpler, more diverse, provincial, and ungainly city that connects all parts of Russia. Yet it is an "outpost of the suppressed peoples of Asia." Thus, Fedotov views St. Petersburg and Moscow as two inevitable biases in Russian history - a Western one, seduced by Peter the Great, and an Asian one, seduced by Moscow. These could be overcome, as he put it, "by a living national spirit." In opposition to these two capitals, he distinguished a third one-Kyiv, with its unspoiled unique Orthodoxy originating in Byzantium, as the cradle of Russia and a spiritual guidance for its revival. "Neither Latinism nor Islam but Hellenism," proclaimed Fedotov. ${ }^{10}$

Certainly, there was some sense of nostalgia for the past, experienced by Fedotov and other émigrés. The material of nostalgia, as many scholars argue, is the past, the "golden age" of childhood and, in more symbolic terms, a "lost paradise," applied either to

Andrew Gurr, Writers in Exile. The Identity of Home in Modern Literature (Sussex: The Harvester Press; New Jersey: Humanities Press, 1981), 14.

Referring to Mykhailo Drahomanov that Ukrainian nationality had been almost dormant by the end of the 19th century, Odinets shared among Russian émigrés an opinion about Ukraine as a young nation, which had just been formed out of the common Russian historical background. See Dmitrii Odinets, "Ukrainskii separatism [Ukrainian Separatism]," Sovremennye zapiski 6o (1936): 444 .

10 Georgii Fedotov, “Tri stolitsy [The Three Capitals]," in Russkaia ideia. Vkrugu pisatelei i myslitelei russkogo zarubezhia, vol. 2 (Moscow: Iskusstvo, 1994), 102-19. 
individuals or ethnic groups." On the other hand, Fedotov's position betrays his pragmatic understanding of history. Realizing the political and ideological significance of Kyiv, the scholar naturally criticized Russian intellectuals who "gave it to Hrushevskyi" and complained that Russian writers had been rather indifferent to the city (he mentioned only "Pecherskiie antiki" (Cave Antics) and Khomiakov's poem "Kiev" (Kyiv, 1839)). In other words, Fedotov is concerned that the Russians experience little attachment to the former "mother of Rus towns" and willy-nilly undermine its imperial identity. ${ }^{2}$

This kind of nostalgia for the idyllic past pertained to the émigré works of the most prominent Russian émigré writer, Ivan Bunin, who considered that Kyiv belonged to Russian culture. ${ }^{13}$ Whereas one cannot deny such a connection, Bunin was far off the mark when he declared the disappearance of the Ukrainian nation. In his novel Zhizn Arsenieva (The Life of Arseniev, 1927-1933) the main hero is quite nostalgic about his early days in "Little Russia" — the author never uses the terms "Ukraine" or "Ukrainians." He piously recollects "Little-Russian" landscapes, khokhlushki (derogatory term for Ukrainian women), folk songs, and Shevchenko as a poet of genius. But for him Ukraine "no longer has history, its historical life ended long ago and forever." ${ }^{14}$ In his growing longing for the past, he tries to appropriate even such a rebel against Russian imperialism as Taras Shevchenko. In reflecting a nineteen-century idyllic picture of the Russian unified world, Bunin followed Kuprin and his predecessors and was clearly out-of-step with the modern nation-building process.

In contrast, when examining Ukrainian émigré writings, Kyiv appears as a marker of a pure Ukrainian identity. Yurii Lypa in his essay "Kyiv, vichne misto" (Kyiv, the Eternal City, 1938) conceptualizes it as an "eternal city" that would be a constant source of national self-affirmation and revival. The metaphor "eternal" is very essential here, as it shows a transcendental meaning of the place to which Ukrainian people belong. Going as far back as to the medieval origin of Kyiv, Lypa recognizes it as a major European multinational centre with the dominance of the local Polianian population. The main spiritual characteristic that was the source of the city's glory was, in his opinion, "a deep feeling of freedom." 15 This was the very characteristic that Lypa counterpoises to the barbarity of the Suzdal land. As an example, he recounts the story of the monk Symon

11 See, e. g., Fred Davis, Yearning for Yesterday: A Sociology of Nostalgia (New York: The Free Press; London: Collier Macmillan Publishers, 1979).

12 All other known examples are mainly referred to the nineteenth century: novels by Mikail Zagoskin (Askoldova mogila (Askold's Grave)), Aleksandr Veltman (Koshchei bessmertnyi (The Immortal Koshchei)) and Nikolai Polevoi (Banket Sviatoslava (Sviatoslav's Feast)); and poems by Vasilii Zhukovskii, Vladimir Benediktov, Kondratii Ryleev, Ivan Kozlov, and Andrei Podolinskii.

13 Thomas Gaiton Marullo, ed., Ivan Bunin: The Twilight of Émigré Russia, 1934-1953. A Portrait From Letters, Diaries, and Memoirs (Chicago: Ivan R. Dee, 2002), 180.

14 Ivan Bunin, Zhizn Arsenieva [The Life of Arseniev] (New York: Izdatelstvo im. Chekhova, 1952), 35 o.

15 Yurii Lypa, "Kyiv, vichne misto [Kyiv, the Eternal City]," in Bii za ukrainsku literaturu by Yurii Lypa (Kyiv: Dnipro, 2004), 296. 
from the Kyivan Cave Monastery (1226) who was sent on a mission to proselytize the "Finnish tribes who called themselves Russian people." In a letter to his friend, the monk Polikarpii, Symon expresses a strong feeling of nostalgia for Kyiv as a center of civilization:

I tell you that all glory and honor that I have obtained here is a piece of shit for me. I tell you that I would be more willing to wallow in the Cave Monastery's mire and be trampled by people, and that I'd be more willing to be a beggar at the pious Cathedral gate, asking for help. It would be better for me to stay in the temple of God's Mother for one day than in these villages for centuries. ${ }^{16}$

Similar views are echoed in the brochure Kyiv $i$ znachinnie tradytsii (Kyiv and the Role of Tradition, 1926) by a Western-Ukrainian writer, scholar, and staunch Catholic, Osyp Nazaruk. Although based on his recollection about his travel/pilgrimage to Kyiv in 1913, the author found it timely and suitable to bring the issue of the historical role of Kyiv to the fore right at the peak of the interwar discussion about Russian versus Ukrainian historical narratives. While enjoying historical sites (e. g., Cave monasteries, the Brotherhood monastery), Nazaruk is saddened that this sacred place "is now appropriated by the one and indivisible Russia"17 and corrupted under foreign influence:

Walking by, I was listening attentively to speaking groups of people. Older people mostly spoke Ukrainian, but younger people and children used only Russian (po-moskovsky). That was the influence of education... It was quite tormenting to listen to how our kids chattered in Russian... And how sad that it was here in Kyiv, in Podil... ${ }^{18}$

Nazaruk wrote about pre-revolutionary Kyiv but his sense of loss can be extended to the Soviet period, since Kyiv was seen in Western Ukraine and in emigration as occupied by the Bolsheviks. He calls Kyiv "the mother of our towns," "the greatest sacred place of our people," 19 and "a sacral place of Ukraine," ${ }^{20}$ which would always be destined to preserve the local way of life, culture, and tradition. Opposed to the communist idea of a future happy society, the author argues that "the people can be educated and taught only on what has already been (on the tradition), and not on what is yet to come (on phantasy)." ${ }^{21}$

16 Lypa, "Kyiv, vichne misto," 289.

17 Osyp Nazaruk, Kyiv i znachinnie tradytsii [Kyiv and the Role of Tradition] (Chicago: Sich in the USA and Canada, 1926), 24.

18 Nazaruk, Kyiv i znachinnie tradytsii, 19.

19 Nazaruk, Kyiv iznachinnie tradytsii, 15 .

20 Nazaruk, Kyiv i znachinnie tradytsii, 23.

21 Nazaruk, Kyiv i znachinnie tradytsii, 29. 
As we can see, this intellectual debate came to a point where it moved from a political to a sacral sphere, which is very essential in symbolic nationalism. Many scholars define nationalism as a kind of surrogate religion and the nation as a "sacred communion of citizens" of the secular age (Anderson, Smith). Smith speaks about the "sacred foundations" of nations, which include a belief in ethnic election, attachment to a sacred territory, an ancestral homeland sanctified by saints and heroes as well as by the tombs and monuments, shared memories of "golden age," and the cult of the "glorious dead." 22 Applying these foundations to Kyiv, one can find claims in both national mythologies that the Russian and Ukrainian people were the chosen people; they consider the city a place of their origin, which was sanctified by the apostle Andrew on Kyivan hills, by heroes (e.g., Kozhumiaka) and historical sites (e.g., monasteries, the Golden Gate); and that the city was glorified as "the mother of Rus towns" and "the cradle of East Slavic civilization." The Russians, however, would accept their Ukrainian brethren into the imperial fold only as a "tribe" or province. If both the Russian and Ukrainian sides claimed Kyiv as its own sacred space, it would be very useful to analyze how it was reflected and sustained in their émigré literature of the period.

Strangely or not, Kyiv was largely outside the Russian mainstream literary discourse in emigration. One can barely find any allusions in the works of such prominent poets as Vladislav Khodasevich, Marina Tsvetaeva, Zinaida Gippius, and Viacheslav Ivanov. Obviously, being foreigners in Kyiv, they preferred to speak about places where they belonged - Moscow and St. Petersburg. Rather than Kyiv, it was European cities that they had visited or where they had lived that inspired their muse (e. g., Tsvetaeva's cycles "Berlin," "Prague," "Stikhi k Chekhii" (Poems to Czech Republic); Gippius's "Belgrade," etc). Mostly those who were born or raised in Kyiv were quite preoccupied with the city, including minor writers, such as Lolo (Leonid Munshtein), Galina Kuznetsova, Aleksandr Bisk, and Gisella Lakhman. However, one may find a significant difference in the presentation of Kyiv: physicality of images and feeling of nostalgia among Russian émigré writers, and mythologization and symbolic representation among their Ukrainian counterparts.

The Russian case can be characterized as "nostalgic hyperrealism" — an "almost obsessive realism that strains to recapture exactly, in minute and exquisite detail, how objects looked then, how people spoke and dressed then, and so forth." ${ }^{23}$ Certainly, in this sense of physicality Kyiv was a precious place of origin for Russian writers and a constant source of lyricism and nostalgic feelings for their past, as it is in one of Lolo's poems (1931): ${ }^{24}$

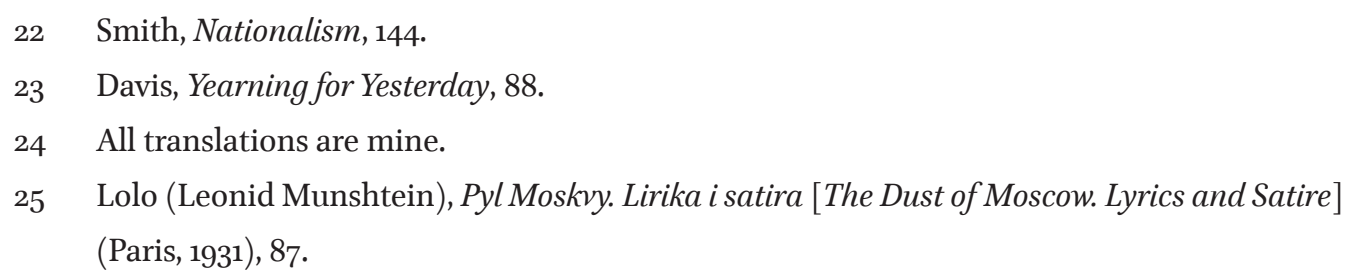


...Our golden autumn,

The autumn of native Kyiv

I'm glad to recollect again.

There - is it lost forever? -

It was a crystal autumn day,

Tender and pure as a baby's breath.

In the sky birds were singing,

The sun gently and graciously

was shining from the heavens... ${ }^{25}$
...Nashu osen zolotuiu,

Osen Kieva rodnogo

Mne otradno vspomnit snova.

Tam - naveki l on utrachen? -

Den osennii byl prozrachen,

Nezhen, chist, kakvzdokh rebenka.

Vnebe ptashki peli zvonko,

Solntse krotko, blagosklonno

Nam svetilo s nebosklona...

Lolo's nostalgic feeling is accompanied by imaginative visits to various Kyivan sites. However symbolic they may seem to be, they appear quite "profaned" by human presence and very personal involvement:

There in my student's years

I glorified nature:

Autumn, the whisper of November,

The Botanical Garden

And the silence of Askold's grave,

The Tsar Garden (distant and dear!),

Our glorious wide Dniepr river,

The presence of a dark-eyed khokhlushka

And sweet ache of a date

On the Vladimir place... ${ }^{26}$
Tam-v studencheskiie gody

Ya vospel dary prirody:

Osen, shepot listopada,

Botanicheskogo sada,

Tish Askoldovoi mogily,

Tsarskii sad (dalekii, milyi!),

Nash zavetnyi Dnepr shirokii

Stan khokhlushki chernookoi,

I svidania trepet sladkii

Na Vladimirskoi ploshchadke...

The physicality of Kyiv is also present in his poem "My otdokhnem," in which he describes his worries of being in the city "under Petliura." As the former head of the Ukrainian revolutionary Directory (1918-1920), Symon Petliura was not only a political and military leader but also the most visible symbol of Ukrainian "separatism" for Russian émigrés and Bolshevik authorities alike. Lolo thus finds Kyiv as a contested territory, in which he does not feel safe and comfortable anymore, the way similar to Bulgakov's Turbin family, which found themselves "stripped of Russian identity and flooded with Ukrainian signs" 27 in a city torn by civil and national liberation wars. The poet is physically attached to the city, as he "graduated from St. Vladimir Kyiv University"; but he is a "Muscovite in his soul," who "since adolescence gives his thoughts and words to Moscow."28

This nostalgic realism and lyrical concreteness are typical in the works of other Russian émigré writers. For Kyivan-born Lakhman these are "the bluish Dnipro river," "the chain bridge," "Askold's grave," and the "Kyivan poplars." ${ }^{29}$ For Kuznetsova this is:

Lolo, Pyl Moskry, 88.

Koznarsky, “Three Novels, Three Cities," 113.

Lolo, Pyl Moskvy, 179 .

Gizella Lakhman, Plennye slova [Captured Words] (New York: Izdanie Kruzhka russkikh poetov v Amerike, 1952). 
The city of my distant childhood, I hear through the splashing ocean, The rustling of the night wind In the branches of your poplars.
Gorod dalnego detstva, Ya slyshu skvoz shum morei, Shelst nochnogo vetra Vvetviakh tvoikh topolei.30

This physicality is further strengthened by real objects brought from Kyiv, as described in Bisk's poem "Rus":

Above us - simply, like an icon lamp, An engraving of the old Kremlin, And a branch from a Kyivan garden This is my Rus. ${ }^{31}$
Nad nami — skromno, kak lampada, Graviura starogo Kremlia, Da vetv iz Kievskogo sada Vot Rus moia.

Bisk's linkage of "an engraving from the old Kremlin" with "a branch from a Kyivan garden" betrays his imperial vision of Kyiv. Lolo's "figure of a dark-eyed khokhlushka" echoes the pastoral images of Ukraine in Bunin's works and adds an exotic and colonial overtone, typical of the colonial/colonized relationship.

This sense of physical attachment to Kyiv is also immanent in the works of the prominent prose writer, Kyivan-born Mark Aldanov. Speaking about the Russian revolution, in the novel Pobeg (Escape) he portrays his native city as a kind of haven to which many Russians could flee from the Bolshevik terror and find food. Although some escapees suddenly discovered their Ukrainian roots and could enjoy freedom from the Bolshevik terror (e. g., Kremenetskii, Yatsenko, and Fomin), they found themselves quite confused in the new historical circumstances of Ukraine's independence and viewed it through an ironic prism as something strange.

A symbolic vision of Kyiv is an exception in the writings of Russian émigré authors. One of them is Sergei Rafalsky, born in the provincial Ukrainian town of Iziaslav. In his retrospective view of Russia's history he goes as far back as early Christianity in his delight in the beauty of the city ("Povest o Skifii" (A Story about the Scythian Land)). ${ }^{32}$ In discussing contemporary events, Vladimir Korvin-Piotrovsky also makes references to the period of Kyivan Rus ("Volkhvy" (The Pagan Wizards), "Plach Yaroslavny" (Yaroslavna's Lament), "Igorevy polki” (Ihor's Regiments)). His local patriotism is, however, focused on his native town of Bila Tserkva and the river Ros. ${ }^{33}$

In contrast, this physicality and nostalgia for Kyiv is almost absent in the works of Ukrainian émigré writers (Yurii Darahan, Yurii Lypa, Oleksa Stefanovych, Yurii Klen,

Poems. An Anthology] (Moscow: Respublika, 1995), 281. 1903-1961] (Paris: Imprimerie Berésniak, 1961). Rafalskii (Paris: Albatros, 1983), 107-18.

Aleksandr Bisk, Chuzhoe i svoe. Izbrannye stikhi, 1903-1961 [Not Mine and Mine. Selected Poems,

Sergei Rafalskii, "Povest o Skifii [A Story about the Scythian Land]," in Za chertoi by Sergei

Vladimir Korvin-Piotrovsky, Porazheniia. Poemy i stikhi o Rossii [The Defeat. Poems about Russia] (Paris: Rifma, 1960). 
etc.). On the other hand, this may be understandable, as none of them were born in Kyiv. It is also difficult to determine what their experience, if any, was of the real city. One may assume that those writers, like Stefanovych and Oksana Liaturynska, who were born in Western Ukraine, a part of interwar Poland, never visited Kyiv. While Ukrainian intellectual and artistic life in the city was due to migration from Ukrainian towns and villages, Kyiv was heavily Russified before the revolution and produced many prominent Russian figures (e. g., Berdiaev, Aldanov, Akhmatova, Bulgakov, Lev Shestov, Serge Lifar). This opposition of physical presence and absence thus explains the largely symbolic perception of Kyiv as a marker of a distinct Ukrainian entity that permeates the works of many writers. In this sense, the city appears not only as a territory but also as a center/capital and a symbol, which represents a people, their culture and identity. Scholars agree that the ethnic homeland is much more than just a territory. Walker Connor, for instance, points out that "...the near universal use of such emotionally charged terms as the motherland, the fatherland, the native land, the ancestral land, land where my fathers died and, not least, the homeland, the territory so identified becomes imbued with an emotional, almost reverential dimension." 34

In this respect, Kyiv is a place of origin of many legends, myths, and fairy-tales in Ukrainian émigré writings. For instance, Lypa included two poems, "Pro shevtsia Kozhumiaku" (About the Tailor Kozhumiaka) and "Pro Sviatu Sofiiu" (About Saint Sophia) in his cycle "Kyivski lehendy" (Kyivan Legends). In "Pro shevtsia Kozhumiaku" the author alludes to the heroic deeds of a legendary Kyivan dweller named Kyrylo Kozhumiaka, who could not refuse children to fight for freedom of their city and country against the Tatar and Mongol aggressors. The poem ends with a prayer-like paean to Kyiv:

Oh, how is Kyiv renowned
Throughout all Ukraine,
And the whole world
From the beginnings to this day
And to the end of time! 35

Oh, how is Kyiv renowned Throughout all Ukraine, From the beginnings to this day And to the end of time!
Oi i slaven Kyiv
Ta po vsii Ukraini,
Ta i na tsilyi svit
Vid viku i donyni
I do kintsia lit!

The use of legends is especially abundant in the works of Natalena Koroleva, who wrote two collections of stories: Lehendy kyivski (Kyivan Legends) and Lehendy Kyivo-Pecherskoho monastyria (Legends of the Kyivan-Cave Monastery). Whereas in the story "Kyrylo Kozhumiaka" she echoes the theme exploited by Lypa, the significant idea of her Kyivan cycle is that this is the land chosen and blessed by God for the Ukrainian people. This idea is particularly dominant in her stories about Archangel Michael ("Mykhailyk") and Apostle Andrew's mission to find the city ("Nerushyma stina" (An Indestructible Wall)).36

34 Walker Connor, "The Impact of Homelands upon Diasporas," in Modern Diasporas in International Politics, ed. Gabriel Sheffer (New York: St. Martin's Press, 1986), 16. 
The case of Natalena Koroleva is especially important, as she was not of the Ukrainian origin and born to a Polish father and a Spanish mother. She lived for several years at her family estate in Volyn (Volyhnia) and later moved to Kyiv where she studied at a finishing school. She also lived in St. Petersburg where she graduated from the Archaeological Institute and Academy of Arts. Although the physical touch of the city might be important for Natalena Koroleva's identity formation, she became Ukrainianized thanks to her husband Vasyl Koroliv-Staryi, a writer and publisher, and that was the milieu in which she found herself in interwar Prague. That milieu of Ukrainian émigrés, being outside their homeland, without their capital city and craving to preserve their history and culture, matched perfectly her own quest to find a place of belonging. With her knowledge of Spanish, French, Italian, Arabic, and Russian, Natalena Koroleva nevertheless chose the Ukrainian language and became a prolific Ukrainian writer.

In the reinforced self-affirmation of Ukrainian émigré writers, historical memory was a very important factor. Not surprisingly, it allowed them to go as far back as to the pre-Christian period, which was not immanent in the works of Russian émigré writers. Ukrainian writers did this to claim a greater rootedness on the territory of Kyiv and Ukraine. Overall, writers like Stefanovych and Liaturynska were more interested in the pagan world, although they did not reject Christianity. Stefanovych's words that the pagan god Perun often "knocks on our shores" is very telling in this respect ("Son Peruna" (Perun's Dream)). The poet seems to cross the boundary of time, as if trying to bind together the remote past and the present in order to emphasize the role of historical memory:

Dnipro is roaring and groaning in the mist, The earth is shuddering, like in convulsions... And in the village they whisper fearfully: No, He will never surrender to them. ${ }^{37}$
Reve ta stohne Dnipr u mli, Zemlia zdryhaietsia, yakv triastsiakh...

I shepchut zliakano v seli:

$O$, Vin nikoly im ne dastsia.

"You have not died yet," writes Liaturynska, referring to the same Perun: "Appear, o god, and come." 38 As the critic Yurii Sherekh noted, the Kyivan Rus period is the most vibrant theme in her works. ${ }^{39}$ It is interesting to note that Liaturynska was cremated after her death according to the pagan custom.

Although Ukrainian writers were mostly preoccupied with the legendary past, Yevhen Malaniuk and Yurii Klen are two writers who try to connect it clearly with the present and the current political agenda. For Klen, "Khreshchatyk Street is covered

Oleksa Stefanovych, Zibrani tvory [Collected Works] (Toronto: Yevshan-zillia, 1975), 79.

38 Oksana Liaturynska, Zibrani tvory [Collected Works] (Toronto: Vydannia Orhanizatsii ukrainok Kanady, 1983), 80. 
with scabies" 40 indicating the worst-ever destruction of this sacred city, now carried out by the Bolsheviks:

Neither the Avars, the Tatars,

Nor the fierce Pechenegs

Were monsters,

Because even Batyi preserved

Your churches and golden domes.

But now, now, now

The modern barbarian

Has trampled on your purity

And covered your soul with manure. ${ }^{41}$
Shcho obry, shcho tatary!

Shcho liutyi pechenih!

To zh ne buly pochvary,

Bo i Batyi berih

Tvoii tserkvy i sviatyni:

Vivtar izlatohlav.

A nyni, nyni, nyni

Divotstvo roztoptav

Tvoie suchasnyi varvar

I dushu zahnoiv.

In the same vein, Malaniuk wrote in his poem "Kyiv" (1931):

Invasion - again. Again Suzdal rushed to destroy.

Mysteries of millennia in the beautiful

Sophia cathedral are preserved,

Which paled but grew brighter and

higher

Like a prayer into the sky. ${ }^{42}$
Znov-navala. Znov Suzdal posunula nyshchyt.

Tainy tysiacholittia $-v$ Sofii

strunkii,

Shcho poblidla, ale shche yasnishe, shche vyshche

Vyrosta, yak molytva, v blakyt.

In another poem, entitled "Kyiv" (1930), Malaniuk clearly counterposed Fedotov's view of the city as one whose civilizational role is to oppose "Asian hordes" and be on guard of "Hellas," a metaphorical name for a revived Ukraine:

It is he-exposed to destruction of

Asian winds - raised his golden profile,

To guard immaculate Hellas

In times of predilections and malice. ${ }^{43}$
Se vin pidnis - viddanyi na zahladu

Vitram aziiskym - zolote cholo,

Shchob sterehty nezbudzhenu Elladu

Nad vyruvanniam prystrastei i zlob.

As we can see, Ukrainian émigré writers often did not differentiate between hordes of the steppe and the Muscovites as representatives of the same civilization. That was a clear attempt on their part to connect the beginning of Russian history to the Mongol

40 1992), 133.

41 Yurii Klen, "Ukraina [Ukraine]," 143-44.

42 Yevhen Malaniuk, Poezii [Poems] (Lviv: Feniks, 1992), 240.

43

Malaniuk, Poezii, 333. 
invasion in the thirteenth century and secure Kyiv for a separate Ukrainian history — the historical scheme elaborated by Hrushevskyi and opposed by most Russian historians.

Speaking about Kyiv in terms of myths, legends, and historical narratives, Ukrainian émigré writers seem to have achieved their main goal — to present the city as the only place of origin and destination, which would always be an eternal source of national self-awareness and a symbol of national revival. This probably accounts for many poems entitled "Kyiv." Darahan in his poem "Kyiv" speaks straightforwardly about the city as a symbol. The lyrical hero sees a "burning cross" over the city, which shows that:

Our glorious tribe

Has not died out! To this day Great Volodymyr governs human settlements

Dispersed like a necklace.

And a cross, outlined above the city,

Flames like a symbol, bright and fiery. ${ }^{44}$
Ne vymer

Nash slavnyi rid! Liudskykh osel namystom

Keruie doteper Velykyi Volodymyr.

Iv nebi symvolom yaskrarym

ivohnystym

Palaie khrest, nakreslenyi nad mistom.

In their optimistic stance, Ukrainian writers view Kyivan sites as those preserving national memory. Klen in his poem "Volodymyr" personifies the monument to Prince Volodymyr, who stands in watch over Ukraine's history:

Gazing at the remote horizon in the spring,

Every year the prince sees: the ice melts away.

And remembers how the savage

Pecheneg and the wild Avars after

a wicked age

Perished without a trace.

And a smile plays on his severe visage. ${ }^{45}$
Vdyvliaiuchys vesnoiu $v$ dalnii

obrii,

Shchoroku bachyt kniaz:

skresaie lid.

I zhaduie, yak po dobi nedobrii

Zahynuly, ne polyshyvshy slid,

I dykyi pechenih, i liuti obry.

I hraie usmikhom suvoryi vyd.

One may ask why is there such a difference in the perceptions of Kyiv? Why did Russian writers abroad not respond to Fedotov's concern about Kyiv as a spiritual centre of Russian revival rather than merely a place of personal value? It can be substantiated that, on one hand, this state reflected a new political reality and existential disorientation after the collapse of the Russian empire. Even though the Soviet government resumed old imperial practices (and that was recognized by Russian

Yurii Darahan, "Kyiv," in Sahaidak by Yurii Darahan (Stemford, Connecticut: Zhyttia i Shkola, 1965), 20. 
émigrés such as Nikolai Ustrialov and Pavel Miliukov), many Russian émigrés actually believed that the Bolsheviks intended to ultimately destroy the old imperial order. Their fear was especially strengthened during the period of so-called indigenization of national cultures in the national republics of the USSR in the 1920 s that was reflected in the émigré press. ${ }^{46}$ Thus accepting the loss of the empire, they were losing their imperial identity and, consequently, losing their attachment to former contested imperial places, claimed by other national groups.

One more answer is provided in Fedotov's concept of three capitals: whereas Russia has its own centers, Moscow and St. Petersburg, which might serve as the cradle of Russian civilization, Ukraine could virtually claim only Kyiv as its place of origin. It seemed that those two Russian centers continued to serve that role for Russian émigrés in interwar Europe with numerous references to these sacred places. For them, these cities were embedded in the poetry of Alexander Pushkin and other writers. Pushkin, the founder of modern Russian literature, appeared the most important figure in the Russian emigration, a symbol of Russian identity ${ }^{47}$ Significantly, the initiation of Pushkin's annual celebrations was specifically aimed at strengthening the Russian community abroad. Speaking about this important venture, the leading politician Vasilii Maklakov noted that there were no such celebrations in Russia before the revolution because a healthy statehood does not need such symbols. ${ }^{48}$ Among the Ukrainian sites, Pushkin focused on the provincial city of Poltava as a more important place and symbol in the ongoing construction of the modern Russian empire. Pushkin's world of the Petrine Mednyi vsadnik (A Bronze Horseman) was dialectically reshaped in another important work, the novel Peterburg (Petersburg, 1916), by Andrei Belyi.

It is also obvious that the image of Kyiv as a sacred place, as suggested by intellectual discussion and presented in literary texts, was more strongly sustained in the Ukrainian émigré milieu. If one is to follow Jackson's and Henrie's categorization of sacred space into three levels in descending order-(1) mystic-religious; (2) homelands;

46 The prominent historian and linguist Petr Bitsilli was fiercely opposed to this process because it threatened all-Russian integrity and seemed unnatural and illogical. He sees the "division of the Russian nation" as forced both by the Bolsheviks and the Ukrainianizers. For the Bolsheviks, it is a "bone" thrown to regions to obtain their support, whereas for Ukrainians it is the only way to implant Ukrainian culture, as it would inevitably lose to Russian culture under the condition of "free competition" — see Petr Bitsilli, Problema russko-ukrainskikh otnoshenii $v$ svete istorii [The Problem of Russain-Ukrainian Relationship in the Light of History] (Prague: Yedinstvo, 1930), 35-36.

47 See Stephanie Sandler, "Pushkin and Identity," in National Identity in Russian Culture: An Introduction, ed. Simon Franklin and Emma Widdis (Cambridge: Cambridge University Press, 2004), 197-216.

48 G. A. Kuzina, “Znachenie 'Dnei russkoi kultury' v zhizni rossiiskoi emigratsii pervoi volny [The Importance of 'The Days of Russian Culture' in the Life of the Russian Emigration of the First Wave]," in Kultura russkogo zarubezhia, ed. A. Kvakin and E. Shulepova (Moscow: Rossiiskii institut kulturologii, 1995), 48. 
and (3) historical sites - then the Ukrainian émigrés would largely embrace the first two categories, whereas the Russian émigrés include the last two categories in a more physical sense. ${ }^{49}$ While the Russians growingly perceived Kyiv as an alienated space, their Ukrainian counterparts felt a direct sense of belonging to Kyiv as a Ukrainian centre surrounded by the Ukrainian population with its distinct language, political and cultural traditions.

This opposition was also sustained in the Soviet period. A Russian imperial image of Kyiv depicted in Mikhail Bulgakov's novel Belaiia Gvardiia (The White Guard, 1925) triggered a strong response from Ukrainian writers, such as Mykola Kulish and Valerian Pidmohylnyi. In Pidmohylnyi's seminal novel Misto (The City, 1927), the main hero Stepan Radchenko, like many of his compatriots, departs his village to conquer the city and legitimize the Ukrainian urban experience. Echoing Pidmohylnyi, a prominent Soviet Ukrainian literary critic, Oleksandr Biletskyi, referred to the October revolution, which established Kyiv as a true Ukrainian city from a provincial city of the Russian empire. In a long list of Soviet Ukrainian writers who wrote about Kyiv he included only two Russians, Vladimir Mayakovky and Aleksei Surkov..$^{50}$ The model of Kyiv as a modern sacral Ukrainian city gained a new impetus after Ukraine's independence since 1991.

\section{Bibliography}

Anderson, Benedict. Imagined Communities: Reflections on the Origin and Spread of Nationalism. London: Verso Editions/NLB, 1983.

Biletskyi, Oleksandr. "Obrazy Kyieva v khudozhnii literaturi [Images of Kyiv in Fiction].” In Zibrannia prats u piaty tomakh by Oleksandr Biletskyi (Kyiv: Naukova dumka, 1966): 539-72.

Bisk, Aleksandr. Chuzhoe i svoe. Izbrannyie stikhi, 1903-1961 [Not Mine and Mine. Selected Poems, 1903-1961]. Paris: Imprimerie Berésniak, 1961.

Bitsilli, Petr. Problema russko-ukrainskikh otnoshenii v svete istorii [The Problem of Russain-Ukrainian Relationship in the Light of History]. Prague: Yedinstvo, 1930.

Bunin, Ivan. Zhizn Arsenieva [The Life of Arseniev]. New York: Izdatelstvo im. Chekhova, $195^{2 .}$.

Connor, Walker. "The Impact of Homelands upon Diasporas." In Modern Diasporas in International Politics, edited by Gabriel Sheffer, 16-46. New York: St. Martin's Press, 1986.

Darahan, Yurii. Sahaidak [A Quiver]. Stamford, Connecticut: Zhyttia i Shkola, 1965.

Davis, Fred. Yearning for Yesterday: A Sociology of Nostalgia. New York: The Free Press; London: Collier Macmillan Publishers, 1979.

49 R. H. Jackson and R. Henrie, "Perception of Sacred Space," Journal of Cultural Geography 3 (1983): 94-107.

$5^{\circ} \quad$ Oleksandr Biletskyi, "Obrazy Kyieva v khudozhnii literaturi [Images of Kyiv in Fiction]," in Zibrannia prats u piaty tomakh by Oleksandr Biletskyi (Kyiv: Naukova dumka, 1966), 539-72. 
Fedotov, Georgii. “Tri stolitsy [The Three Capitals].” In Russkaia ideia. Vkrugu pisatelei i myslitelei russkogo zarubezhia, vol. 2, 102-19. Moscow: Iskusstvo, 1994.

Glagolev, Andrei. Zapiski russkogo puteshestvennika [Notes of a Russian Traveller]. 2nd ed. St. Petersburg, 1845 .

Gurr, Andrew. Writers in Exile The Identity of Home in Modern Literature. Sussex: The Harvester Press; New Jersey: Humanities Press, 1981.

Izmailov, Vladimir. Puteshestvie v Poludennuiu Rossiiu [A Travel to South Russia], vol. 1. Moscow, 1800.

Jackson, R. H., and R. Henrie. "Perception of Sacred Space." Journal of Cultural Geography 3 (1983): 94-107.

Kirkevich, Viktor. Vremia Romanovykh: Kiev v imperii [The Time of the Romanovs: Kyiv in Empire]. Kyiv: Tekhnika, 2004.

Klen, Yurii. "Ukraina [Ukraine]." In Tvory by Yurii Klen, vol. 1. New York: Shevchenko Scientific Society, 1992.

Kohut, Zenon. History as a Battleground: Russian-Ukrainian Relations and Historical Consciousness in Contemporary Ukraine. Saskatoon: Heritage Press, 2001.

Koroleva, Natalena. Predok [The Predecessor]. Kyiv: Dnipro, 1991.

Korvin-Piotrovsky, Vladimir. Porazheniia. Poemy i stikhi o Rossii [The Defeat. Poems about Russia]. Paris: Rifma, 196o.

Koznarsky, Taras. “Three Novels, Three Cities.” In Modernism in Kyiv: Kiev/Kÿ̈/Kiev/ Kijów/Kiey: Jubilant Experimentation, edited by Irena R. Makaryk and Virlana Tkacz, 98-137. Toronto: University of Toronto Press, 2006.

Kuzina, G. A. “Znachenie 'Dnei russkoi kultury' v zhizni rossiiskoi emigratsii pervoi volny [The Importance of 'The Days of Russian Culture' in the Life of the Russian Emigration of the First Wave]." In Kultura russkogo zarubezhia, edited by A. Kvakin and E. Shulepova, 46-57. Moscow: Rossiiskii institut kulturologii, 1995.

Kuznetsova, Galina. In Vernutsia v Rossiiu - stikhami. Antologiia [Coming Back to Russia — with Poems. An Anthology], 281-83. Moscow: Respublika, 1995.

Lakhman, Gizella. Plennye slova [Captured Words]. New York: Izdanie Kruzhka russkikh poetov v Amerike, $195^{2}$.

Liaturynska, Oksana. Zibrani tvory [Collected Works]. Toronto: Vydannia Orhanizatsii ukrainok Kanady, 1983.

Lolo (Leonid Munshtein). Pyl Moskry. Lirika i satira [The Dust of Moscow. Lyrics and Satire]. Paris, 1931.

Lypa, Yurii. "Kyiv, vichne misto [Kyiv, the Eternal City]." In Bii za ukrainsku literaturu by Yurii Lypa, 288-305. Kyiv: Dnipro, 2004.

Lypa, Yurii. Poeziia [Poetry]. Toronto: Likarske tovarstvo Pivnichnoi Ameryky, 1967.

Malaniuk, Yevhen. Poezii [Poems]. Lviv: Feniks, 1992.

Marullo, Thomas Gaiton, ed. Ivan Bunin: The Twilight of Émigré Russia, 1934-1953. A Portrait From Letters, Diaries, and Memoirs. Chicago: Ivan R. Dee, 2002.

Nazaruk, Osyp. Kyiv i znachinnie tradytsii [Kyiv and the Role of Tradition]. Chicago: Sich in the USA and Canada, 1926. 
Odinets, Dmitrii. "Ukrainskii separatism [Ukrainian Separatism]." Sovremennye zapiski 6o (1936): 438-48.

Shenrok, V. I., ed. Pisma N. V. Gogolia [Letters by N. V. Gogol], vol. 1. St. Petersburg, 1901. Plokhy, Serhii. Unmaking Imperial Russia: Mykhailo Hrushevsky and the Writing of Ukrainian History. Toronto: University of Toronto Press, 2005.

Rafalskii, Sergei. Za chertoi [Across the Border Line]. Paris: Albatros, 1983.

Sandler, Stephanie. "Pushkin and Identity." In National Identity in Russian Culture: An Introduction, edited by Simon Franklin and Emma Widdis, 197-216. Cambridge: Cambridge University Press, 2004.

Sherekh, Yurii. “Introduction." In Zibrani tvory by Oksana Liaturynska. Toronto: Vydannia Orhanizatsii ukrainok Kanady, 1983.

Smith, Anthony. Nationalism: Theory, Ideology, History. Cambridge: Polity Press, 2001.

Smith, Anthony. Ethno-Symbolism: A Cultural Approach. London; New York: Routledge, 2009.

Stefanovych, Oleksa. Zibrani tvory [Collected Works]. Toronto: Yevshan-zillia, 1975.

Mykola Iv. Soroka received his Candidate's degree in Ukrainian Literature at the Taras Shevchenko National University of Kyiv (1995) and his PhD in Modern Languages and Cultural Studies at the University of Alberta (2005). He is the author of the monographs Zorova poeziia $v$ ukrainskii literaturi kintsia XVI-XVIII st. (Visual Poetry in Ukrainian Literature at the End of the 16th-18th Centuries) (Kyiv, 1997) and Faces of Displacement: The Writings of Volodymyr Vynnychenko (Montreal, 2012). His recent publications explore Ukrainian-Russian cultural contacts of the interwar period in emigration, and issues of modernity, displacement, and travel in Ukrainian literature. 